\title{
Subjective Norms and Intention- A Study of Crowdfunding in India
}

\author{
Hasnan Baber ${ }^{1}$ \\ ${ }^{1}$ Endicott College of International Studies, Woosong University, Daejeon, South Korea \\ Correspondence: Hasnan Baber, Assistant Professor, Endicott College of International Studies, Woosong University, \\ Daejeon, South Korea.
}

Received: September 2, 2019

Accepted: October 4, 2019

Online Published: October 9, 2019

doi:10.5430/rwe.v10n3p136

URL: https://doi.org/10.5430/rwe.v10n3p136

\begin{abstract}
The study is aimed to explore the factors of subjective norms and their influence on shaping the intention of people to participate in crowdfunding. Data was collected from 155 respondents who have been involved in one or many crowdfunding campaigns as a contributor or fundraiser. Data was analyzed using various statistical tools like data reliability test, factor analysis, correlation, and regression. It was found that intention to participate in crowdfunding is shaped by the influence of family and friends and people have high motivation to comply with the approval of these reference groups. Influence of other reference groups like a supervisor, teacher, neighbor, social network friend, etc. has no impact on shaping the intention of people towards crowdfunding. The study will be useful for crowdfunding platforms to understand the influence of referent groups on people regarding crowdfunding participation.
\end{abstract}

Keywords: subjective norms, intention, crowdfunding, India

JEL Codes: A13, B26, D6

\section{Introduction}

Crowdfunding $(\mathrm{CF})$ is a broad term which means the process of raising funds usually small amounts from a large population known as the crowd to fund a business project, cause, loan or other financial need through the identified platform. Peer to peer lending enables companies and start-ups to raise funds as a loan for which they have to pay interest. In Equity crowdfunding (ECF) start-ups and companies issue shares to the investors while raising funds through crowdfunding and bear profits and losses. Peer-to-peer lending and ECF are popular among the investors for financial returns while Donation-based and reward-based crowdfunding is based on social benefits, for people who are concern about supporting social causes without expecting any financial return. Peer to peer lending and ECF have got the attention of governments also to encourage the progress of Small and Medium Enterprises (SME'S).

In Peer to peer lending investors or businesses contribute small amounts and when funds are collected in bulk, it is transferred to the fundraiser. The interest is determined by the platform based on the risk associated with the project. The interest rate should be greater than the regular saving interest rate at the bank so that investors will be motivated to invest in crowdfunding rather than keeping a bank which is more secure. The interest rate should less than the regular interest rate on the loan from banks so that borrowers prefer to raise funds through crowdfunding. Some platforms target niche business segments and raise funds in only these areas like education financing, gifts, consumption, real estate and many more.

Kirby and Worner (2014) attributed the financial crisis of 2008 to the growth and expansion of crowdfunding. The financial crisis has made small businesses especially start-ups to face difficulty to obtain capital as banks are becoming more careful and reluctant to provide loans (Baber, 2019a). Crowdfunding offers these start-ups an opening to start their ventures, to turn their dreams into reality (Nordin, Ismail, \& Zainudddin, 2018).

Normative belief can be defended as a belief of the person that the social group he belongs to will approve or disapprove some action. The theory of reasoned action proposed by Fishbein and Ajzan (1975) suggests that normative belief has an influence on the intention to do some action or abstain from doing an action. Subjective norms evaluate the observed social forces to act or not to act particular conduct and comprise of two factors which are multiplicatively combined. The first factor is called as normative belief which means to assess the opinion of people who are most important to the person as to whether a person should execute the conduct or not and the second factor is the motivation to comply which means the level of conviction to follow the referent group with these beliefs. 
Therefore, individuals will perform a behavior which is from the referent group to which the individual has more desire to comply (Ham et al., 2015).

\section{Literature Review}

The Theory of Reasoned Action proposes that both normative belief and motivation to comply can together influence the intentions to do or not to do an action (Fishbein \& Ajzen, 1976). Fishbein \& Ajzen, (1975) suggest that normative belief should be weighted with motivation to comply with a particular social group a person belongs to or aspires to join. Theory of Reasoned Action conceives that normative beliefs attributed to a definite social group, multiplied by the motivation to comply with that group, then averaged across all relevant social reference groups like family and friends, form subjective norms about doing or not doing an action. Intentions can one of the important predictors about the actual performance (Eagly \& Chaiken, 1993; Yunuset al., 2018; Mbabazi, 2018).

Other than family and friends, social pressure can come from role models and supervisors as well (Krithika, \& Venkatachalam, 2014). To understand the qualification of normative belief associated with a social class, there is a need to measure the motivation to comply with that social class (Ajzen, \& Fishbein, 1973). In other words, it is not enough to understand what other people think that a person should do or not to do but also the extent of motivation for that person to comply with that thought (Ajzen, \& Fishbein, 1972). Higher levels of motivation to comply with the thoughts of the social group will have a high impact of normative belief and will lead to higher intention to do or not to do a behavior. While as a lower level of motivation to comply will be associated with a low impact of normative belief and hence will not influence the intentions to that extent (Fishbein \& Ajzen, 1975; Binyamin, Rutter, $\&$ Smith, 2018). There is always a reason for a person to behave as per the wants and requirements of the social group. The person may feel that the social group have more expertise in this field, he may also feel a threat of punishment or rejection from the group and may look upon to some rewards, appreciation or inclusion in the group (Etcheverry, \& Agnew, 2004; Kashif, et al., 2018).

The theory of Reasoned Action has been employed by various studies to examine behavior of humans in the fields of marketing, psychology and entrepreneurship (Armitage and Conner 1999; Buttle and Bok 1996; Conner \& Abraham 2001; Shan, \& King, 2015; Hasbullah et al., 2016; Tiwari, \& Bhat, 2017). Many studies in social science have supported the proposition that subjective norms are the vital predictor of a person's behavioral intentions (Conner, Kirk, Cade and Barrett 2001; Morris, \& Liu, 2015; Minton, et al., 2018; Bok, \& Park, 2019). Various authors studied the subjective norm on adopting banking and found it the most important factor in shaping the intention of people (Gumel et al. 2015; Hanudin et al., 2014; Abduh et al., 2011). Lujja et al. (2016) on the contrary found that the referent group has no significant influence on shaping the intention to adopt banking. Lajuni et al. (2017) suggested that a person will perform a behavior as expected by the social group under the pressure of the same even he may not be in favor of doing the action. Chau and $\mathrm{Hu}$ (2001) and Lewis et al. (2003) studied the intention to adopt information technology and concluded that subjective norm is an insignificant contributing factor. Evers, Lourenço, $\&$ Beije, (2012) studied the success factors of crowdfunding and pointed out that social impact and engagement are the two important success factors of the crowdfunding campaign. Pan, \& Liu, (2018) stated that strong motivation to comply with referent groups will lead to the high inclination to participate in equity crowdfunding projects. Astebro et al. (2018) concluded that early contributors gather and disseminate information to their referent groups which encourage other contributors to invest. Shneor and Munim (2019) studied the reward-based crowdfunding and proposed that factors like attitude, self-efficacy, and subjective norms have a direct relationship with the contribution behavior. Baber (2019b) studied the factors which shape the attitude of the people towards participating in crowdfunding and concluded that prior experience of technology; financial markets and influence of referent groups have a relationship with the development of attitude towards crowdfunding.

\section{Analysis}

A 5-point Likert scale was used to gather data from 155 respondents where $1=$ strongly disagree, $2=$ disagree, and 5 = strongly agree. A simple random sampling technique was used to gather data from people who have already participated in crowdfunding campaigns as a fundraiser or funders. Most of the respondents were in the age of between 23-40 years, around 90\%. This age group is mostly technology users and has an understanding of the crowdfunding process. Most of the people were single around 63\%. Respondents were mostly educated and the majority of people were graduate or undergraduate. In order to understand the influence of family on intention, it was important o understand the structure of the family. Most of the respondents were from the nuclear family while a good number of people were from a joint family. To understand the influence of friends, a question was asked about the 'number of friends'. Most of the people, around $65 \%$ of people have 3 or 4 friends. Apart from family and friends, people were asked whom they follow and most the people marked teacher then religious or social group and social 
networking friends. People ranked the referent groups and family were ranked number one by $45 \%$ of respondents and the friend by $35 \%$ of respondents.

Table 1. Sample descriptive statistics

\begin{tabular}{|c|c|c|c|}
\hline Variable & Categories & Frequency & Percentage \\
\hline \multirow[t]{4}{*}{ Age } & $18-22$ & 3 & 1.9 \\
\hline & $23-30$ & 65 & 41.9 \\
\hline & $31-40$ & 77 & 49.7 \\
\hline & $41-50$ & 10 & 6.5 \\
\hline \multicolumn{4}{|c|}{ Marital Status } \\
\hline & Single & 98 & 63.2 \\
\hline & Married & 57 & 36.8 \\
\hline \multicolumn{4}{|l|}{ Gender } \\
\hline & Male & 125 & 80.6 \\
\hline & Female & 30 & 19.4 \\
\hline \multicolumn{4}{|c|}{ Educational Background } \\
\hline & Diploma & 5 & 3.2 \\
\hline & Undergraduate & 76 & 49.0 \\
\hline & Graduate & 71 & 45.8 \\
\hline & Doctorate Degree & 3 & 1.9 \\
\hline \multicolumn{4}{|c|}{ Family structure } \\
\hline & Nuclear family & 73 & 47.1 \\
\hline & Joint family & 58 & 37.4 \\
\hline & Living alone & 24 & 15.5 \\
\hline \multicolumn{4}{|c|}{ Number of friends } \\
\hline & 2 & 23 & 14.8 \\
\hline & 3 & 53 & 34.2 \\
\hline & 4 & 46 & 29.7 \\
\hline & 5 & 28 & 18.1 \\
\hline & more than 5 & 5 & 3.2 \\
\hline \multicolumn{4}{|c|}{ Person/ group you follow other than family and friends } \\
\hline & Teacher/s & 72 & 46.5 \\
\hline & Boss/Supervisor & 9 & 5.8 \\
\hline & Advisor & 9 & 5.8 \\
\hline & Neighbor & 9 & 5.8 \\
\hline & Religious or social group & 24 & 15.5 \\
\hline & Social networking friends & 24 & 15.5 \\
\hline & None & 8 & 5.2 \\
\hline \multicolumn{4}{|c|}{ Referent Group ranking (Rank 1) } \\
\hline & Family & 71 & 45.8 \\
\hline & Friends & 55 & 35.5 \\
\hline & Others & 29 & 18.7 \\
\hline
\end{tabular}




\subsection{Reliability Analysis}

Reliability (internal consistency and stability) of the data was tested using Cronbach's alpha coefficient (Cronbach, 1951). The Cronbach alpha coefficients for all the constructs were above 0.75 implying that the data used in the study was reliable.

Table 2. Reliability analysis

\begin{tabular}{lll}
\hline Dimension & Items & Cronbach's alpha \\
\hline Influence of Family & 6 & .927 \\
\hline Influence of Friends & 5 & .965 \\
\hline Influence of other reference groups & 5 & .934 \\
\hline Motivation to comply with reference groups & 6 & .962 \\
\hline Intention & 6 & .931 \\
\hline Combined scale & $\mathbf{2 6}$ & $\mathbf{. 9 2 6}$ \\
\hline
\end{tabular}

\subsection{Descriptive Statistics}

Descriptive statistics results of constructs are presented in Table 3. Statistical means and standard deviations are shown to review the collected data as agreeing to Field (2009), means characterize an overview of the data, and standard deviations denote wellness of means to signify the data. The dependent variable, intention to adopt crowdfunding has a mean value of 4.07 , while as standard deviation is 0.74 . This implies that on an average, Indians have high intention to use and adopt the crowdfunding process to raise or contribute funds for a project or cause. However, the mean of influence of family is slightly high with less standard deviation more than friends which are interesting in the case of technology-oriented adoption. Motivation to comply with any reference group is high so people are motivated to follow their reference groups.

Table 3. Descriptive statistics

\begin{tabular}{llllll}
\hline & $\mathbf{N}$ & Minimum & Maximum & Mean & Std. Deviation \\
\hline Influence of Family & 155 & 3.00 & 5.00 & 3.9839 & .52491 \\
\hline Influence of Friends & 155 & 2.60 & 5.00 & 3.7174 & .82958 \\
\hline $\begin{array}{l}\text { Influence of other reference } \\
\text { groups }\end{array}$ & 155 & 3.00 & 5.00 & 3.6581 & .58774 \\
\hline $\begin{array}{l}\text { Motivation to comply } \\
\text { reference groups }\end{array}$ & 155 & 2.75 & 5.00 & 4.0935 & .81192 \\
\hline \begin{tabular}{l} 
Intention \\
\hline
\end{tabular} & 155 & 2.17 & 4.83 & 4.0742 & .74418 \\
\hline
\end{tabular}

Variance inflation factor (VIF) should be reported for all regression models to investigate the potential of collinearity problem among independent variables is shown in table 4 . The model will not give absolute results for regression analysis if there will be a perfect linear correlation among the independent variables. The values of the variance inflation factor should be greater than 5 and at the same time tolerance level should be less than 0.1(Henseler et al., 2015). In this study, values are reasonable and there is no evident relationship between independent variables and thus there is no problem of multicollinearity with this model.

Table 4. Collinearity statistics

\begin{tabular}{lll}
\hline Variables & Tolerance & VIF \\
\hline Influence of Family & 0.912 & 1.096 \\
\hline Influence of Friends & 0.789 & 1.267 \\
\hline Influence of other reference groups & 0.980 & 1.021 \\
\hline Motivation to comply with reference groups & 0.837 & 1.195 \\
\hline
\end{tabular}


In Table 5, the Value of KMO is 0.879 which acceptable and counted as good whereas Barlett's test of sphericity is significant at 325 degrees of freedom. This signifies that data is appropriate and valid for factor analysis (Barrett et al., 2005; Bartlett, 1954).

Table 5. KMO and Bartlett's Test

\begin{tabular}{lll}
\hline \multicolumn{2}{l}{ Kaiser-Meyer-Olkin Measure of Sampling Adequacy. } & .879 \\
\hline Bartlett's Test of Sphericity & Approx. Chi-Square & 5253.054 \\
\cline { 2 - 3 } & df & 325 \\
\cline { 2 - 3 } & Sig. & .000
\end{tabular}

In Table 6, To reduce the factors into relevant and similar variables, Exploratory factor analysis was done and factor loading for all items was > 0.5 (Kaiser, 1974). For principal component analysis, Varimax rotation with Kaiser Normalization is used for this study. Five components were extracted from 26 items of subjective norms and intention.

Table 6. Factor analysis

\begin{tabular}{|c|c|c|c|c|c|}
\hline & Family & Friends & Others & Motivation & Intention \\
\hline Famin 1 & .867 & & & & \\
\hline Famin 2 & .868 & & & & \\
\hline Famin3 & .816 & & & & \\
\hline Famin4 & .830 & & & & \\
\hline Famin5 & .820 & & & & \\
\hline Famin6 & .850 & & & & \\
\hline Friin1 & & .928 & & & \\
\hline Friin2 & & .925 & & & \\
\hline Friin3 & & .903 & & & \\
\hline Friin4 & & .869 & & & \\
\hline Friin5 & & .654 & & & \\
\hline Other1 & & & .874 & & \\
\hline Other2 & & & .932 & & \\
\hline Other3 & & & .892 & & \\
\hline Other4 & & & .895 & & \\
\hline Motcom1 & & & & .943 & \\
\hline Motcom2 & & & & .932 & \\
\hline Motcom3 & & & & .816 & \\
\hline Motcom4 & & & & .926 & \\
\hline Intention 1 & & & & & .655 \\
\hline Intention2 & & & & & .767 \\
\hline Intention3 & & & & & .642 \\
\hline Intention4 & & & & & .651 \\
\hline Intention5 & & & & & .836 \\
\hline Intention6 & & & & & .829 \\
\hline
\end{tabular}


To measure the correlation between the four independent and one dependent variable, Pearson's correlation of coefficient analysis was conducted. There is a strong correlation between intention and influence of friends followed by a moderate correlation of motivation to comply with reference groups and then below moderate correlation with the influence of family. The influence of other reference group variable does not demonstrate any correlation with the intention to adopt crowdfunding. Motivation to comply has a weak correlation with the influence of family and friends but no association with other referent groups.

Table 7. Pearson's correlation of coefficient
(1)
(2)
(3)
(4)
(5)

\begin{tabular}{|c|c|c|c|c|c|}
\hline Influence of Family (1) & 1 & & & & \\
\hline Influence of Friends (2) & $.285^{* *}$ & 1 & & & \\
\hline Influence of other reference groups (3) & .026 & .133 & 1 & & \\
\hline Motivation to comply with reference groups (4) & $.184^{*}$ & $.394^{* *}$ & .098 & 1 & \\
\hline Intention (5) & $.445^{* *}$ & $.731^{\text {** }}$ & .032 & $.536^{* * *}$ & 1 \\
\hline
\end{tabular}

In Table 8, regression results are shown. It can be seen that three independent variables- Influence of family, Influence of friends and Motivation to comply with reference groups have a significant influence on the behavioral intention to adopt or participate in crowdfunding campaign while as Influence of other reference groups like a teacher; boss, etc. has no association with intention. The value of adjusted $\mathrm{R}^{2}$ value is 0.655 which means $65.5 \%$ variance in behavioral intention is explained by these four variables, which is quite good in the case of behavioral study.

Table 8. Regression analysis

\begin{tabular}{llll}
\hline Independent variables & $\boldsymbol{\beta}$ & $\boldsymbol{t}$-value & $\boldsymbol{p}$-value \\
\hline Influence of Family & .334 & 4.750 & $.000^{*}$ \\
\hline Influence of Friends & .507 & 10.595 & $.000^{*}$ \\
\hline Influence of other reference groups & -.097 & -1.601 & .111 \\
\hline Motivation to comply with reference groups & .254 & 5.351 & $.000^{*}$ \\
\hline
\end{tabular}

Notes: Significance at: ${ }^{*} \mathrm{p}<0.01, \mathrm{R}^{2}=0.664$, adjusted $\mathrm{R}^{2}=.655$.

Dependent variable: Intention

\section{Discussion}

People live in a society where they are influenced by the people whom they admire and follow. Many studies have established that reference groups influence our decision making. Crowdfunding is gaining popularity, so it is important to understand the impact of referent groups and motivation to comply with these groups to understand the influence of subjective norms on the intention to participate in crowdfunding as contributors or fundraisers. Family and friends are considered as first and primary referent groups which influence the decision making. The results suggest that the influence of family has an impact on shaping the decision of people to participate in crowdfunding. Approval of family is important in Indian societies as the culture advocates the same. People require the approval of families before they participate in any crowdfunding campaign. The influence of friends has a high correlation with the intention of participating in crowdfunding. Technology suggestions and recommendations are often considered from the same aged people who are well-versed with technology rather than parents who don't have much knowledge of technology or have started using technology in recent times. Friends and peers are often updated with 
new technological advances and it is easy for this group to understand the process and working of technological innovations. Crowdfunding being a technology-oriented method of raising funds so people relay and get influenced more from the group who has an understanding of such innovation. Respondents were mainly millennia's and they are often seen engaged with their friends on social networking sites and the same is true about India where the majority of the population is young unlike the rest of the world.

People are also influenced by the referent groups they admire or follow as role-model. The results show that there is no significant relation of such a group on the intention to participate in crowdfunding. Motivation to comply is really to important measure to check the level of motivation people have to comply with the approval or disapproval of the referent groups. The study found that people are highly motivated to comply with the referent group which has an influence on them. There is a good correlation between the motivation to comply with family and friends referent groups which indicate that people are more obliged to follow these two referent groups. High motivation to follow these groups will lead to high influence of these groups on a person and vice versa.

\section{Conclusion}

The study was an attempt to check the influence of various referent groups on the intention to participate in crowdfunding. The basic referent groups are family and friends, in addition, other referent groups like teachers, supervisors, etc. were taken as factors of normative belief. The motivation to comply with these referent groups was added to measure how much a person is motivated to follow these referent groups. Together all these three factors of referent groups and motivation to comply formed subjective norm and then the influence of all these factors was measured on the intention to participate in crowdfunding as a contributor or fundraiser. The results suggested that the influence of family and friends and motivation to comply with these two referent groups has a positive influence on shaping the intention to participate in crowdfunding. The results support the findings of Shneor \& Munim (2019) that suggested subjective norms are positively associated with financial-contribution and information-intentions but in contrast with (Chen et al., 2019) that found no association between subjective norms and intention to donate money through crowdfunding. The future study may take more referent groups or other states of India to measure the subjective norm which shapes the intention of joining a crowdfunding campaign.

\section{Practical Implications}

The results of this study will help crowdfunding platforms to understand social influence on the people which may shape their intention of participating in crowdfunding platforms. The crowdfunding platforms should start referral program benefits to the existing contributors and encourage them to be word-of-mouth for their platform and campaigns which nay gather good crowd.

\section{References}

Abduh, M., Duasa, J., \& Omar, M. A. (2011). Factors influence depositors' withdrawal behavior in Islamic banks: A theory of reasoned action. World Academy of Science, Engineering and Technology, 60, 2074-2079.

Ajzen, I., \& Fishbein, M. (1972). Attitudes and normative beliefs as factors influencing behavioral intentions. Journal of Personality and social Psychology, 21(1), 1. https://doi.org/10.1037/h0031930

Ajzen, I., \& Fishbein, M. (1973). Attitudinal and normative variables as predictors of specific behavior. Journal of personality and Social Psychology, 27(1), 41. https://doi.org/10.1037/h0034440

Armitage, C. J., \& Conner, M. (1999). distinguishing perceptions of control from self - efficacy: Predicting consumption of a low-fat diet using the theory of planned behavior 1. Journal of Applied Social Psychology, 29(1), 72-90. https://doi.org/10.1111/j.1559-1816.1999.tb01375.x

Astebro, T. B., Sierra, M. F., Lovo, S., \& Vulkan, N. (2018). Herding in Equity Crowdfunding. Working Paper. https://doi.org/10.2139/ssrn.3084140

Baber, H. (2019a). A framework for Crowdfunding platforms to match services between funders and fundraisers. Journal of Industrial Distribution \& Business, 10(4), 25-31. https://doi.org/10.13106/ijidb.2019.vol10.no4.25

Baber, H. (2019b). Factors Underlying Attitude Formation Towards Crowdfunding in India. International Journal of Financial Research, 10(4), 46-54. https://doi.org/10.5430/ijfr.v10n4p46

Barrett, K. C., \& Morgan, G. A. (2005). SPSS for intermediate statistics; use and interpretation lawrence erlbaum associates. Publishers Mahwah, New Jersey London, England.

Bartlett, M. S. (1954). A note on the multiplying factors for various $\chi 2$ approximations. Journal of the Royal Statistical Society, Series B (Methodological), 296-298. https://doi.org/10.1111/j.2517-6161.1954.tb00174.x 
Binyamin, S. S., Rutter, M. J., \& Smith, S. (2018). The Influence of Computer Self-Efficacy and Subjective Norms on the Students' Use of Learning Management Systems at King Abdulaziz University. International Journal of Information and Education Technology, 8(10), 693-699. https://doi.org/10.18178/ijiet.2018.8.10.1124

Bok, M. J., \& Park, N. E. (2019). The Effect of Behavior Attitude and Subjective Norms on Behavior Intention in Food Festival. Journal of the Korea Society of Computer and Information, 24(4), 177-183.

Buttle, F., \& Bok, B. (1996). Hotel marketing strategy and the theory of reasoned action. International Journal of Contemporary Hospitality Management, 8(3), 5-10. https://doi.org/10.1108/09596119610115943

Chau, P. Y., \& Hu, P. J. H. (2001). Information technology acceptance by individual professionals: A model comparison approach. Decision sciences, 32(4), 699-719. https://doi.org/10.1111/j.1540-5915.2001.tb00978.x

Chen, Y., Dai, R., Yao, J., \& Li, Y. (2019). Donate Time or Money?. The Determinants of Donation Intention in Online Crowdfunding. Sustainability, 11(16), 4269. https://doi.org/10.3390/su11164269

Conner, M., \& Abraham, C. (2001). Conscientiousness and the theory of planned behavior: Toward a more complete model of the antecedents of intentions and behavior. Personality and Social Psychology Bulletin, 27(11), 1547-1561. https://doi.org/10.1177/01461672012711014

Conner, M., Kirk, S. F., Cade, J. E., \& Barrett, J. H. (2001). Why do women use dietary supplements? The use of the theory of planned behaviour to explore beliefs about their use. Social science \& medicine, 52(4), 621-633. https://doi.org/10.1016/S0277-9536(00)00165-9

Cronbach, L. J. (1951). Coefficient alpha and the internal structure of tests. Psychometrika, 16(3), 297-334. https://doi.org/10.1007/BF02310555

Eagly, A. H., \& Chaiken, S. (1993). The psychology of attitudes. Harcourt Brace Jovanovich College Publishers.

Etcheverry, P. E., \& Agnew, C. R. (2004). Subjective norms and the prediction of romantic relationship state and fate. Personal Relationships, 11(4), 409-428. https://doi.org/10.1111/j.1475-6811.2004.00090.x

Evers, M., Lourenço, C., \& Beije, P. (2012). Main drivers of crowdfunding success: a conceptual framework and empirical analysis. Erasmus Universiteit.

Field, A. (2009). Discovering statistics using SPSS. Sage publications.

Fishbein, M., \& Ajzen, I. (1975). Belief, attitude, and behavior: An introduction to theory and research. Reading, Mass.: Addison Wessley.

Fishbein, M., \& Ajzen, I. (1976). Misconceptions about the Fishbein model: Reflections on a study by Songer-Nocks. Journal of Experimental Social Psychology, 12(6), 579-584. https://doi.org/10.1016/0022-1031(76)90036-6

Gumel, A. M., Othman, M. A., \& Yusof, R. M. (2015). Critical insights into an integrated literature review on customers' adoption of Islamic banking research. International Journal of Scientific Research and Innovative Technology, 2(6), 45-57.

Ham, M., Jeger, M., \& Frajman Ivković, A. (2015). The role of subjective norms in forming the intention to purchase $\begin{array}{lllll}\text { green food. Economic research-Ekonomska istraživanja, } & \text { 28(1), }\end{array}$ https://doi.org/10.1080/1331677X.2015.1083875

Hanudin, E., Sukmawati, S. T., Radjagukguk, B., \& Yuwono, N. W. (2014). The effect of humic acid and silicic acid on $\mathrm{P}$ adsorption by amorphous minerals. Procedia Environmental Sciences, 20, 402-409. https://doi.org/10.1016/j.proenv.2014.03.051

Hasbullah, N. A., Osman, A., Abdullah, S., Salahuddin, S. N., Ramlee, N. F., \& Soha, H. M. (2016). The relationship of attitude, subjective norm and website usability on consumer intention to purchase online: An evidence of Malaysian youth. Procedia Economics and Finance, 35, 493-502. https://doi.org/10.1016/S2212-5671(16)00061-7

Henseler, J., Ringle, C. M., \& Sarstedt, M. (2015). A new criterion for assessing discriminant validity in variance-based structural equation modeling. Journal of the Academy of Marketing Science, 43(1), 115-135. https://doi.org/10.1007/s11747-014-0403-8

Kaiser, H. F. (1974). An index of factorial simplicity. Psychometrika, 39(1), 31-36. https://doi.org/10.1007/BF02291575 
Kashif, M., Zarkada, A., \& Ramayah, T. (2018). The impact of attitude, subjective norms, and perceived behavioural control on managers' intentions to behave ethically. Total Quality Management \& Business Excellence, 29(5-6), 481-501. https://doi.org/10.1080/14783363.2016.1209970

Kirby, E., \& Worner, S. (2014). Crowd-funding: An infant industry growing fast. IOSCO Research Department.

Krithika, J., \& Venkatachalam, B. (2014). A study on impact of subjective norms on entrepreneurial intention among the business students in Bangalore. IOSR Journal of Business and Management, 16(5), 48-50. https://doi.org/10.9790/487X-16534850

Lajuni, N., Wong, W. P. M., Yacob, Y., Ting, H., \& Jausin, A. (2017). Intention to use Islamic banking products and its determinants. International Journal of Economics and Financial Issues, 7(1).

Lewis, W., Agarwal, R., \& Sambamurthy, V. (2003). Sources of influence on beliefs about information technology use: An empirical study of knowledge workers. MIS quarterly, 657-678. https://doi.org/10.2307/30036552

Lujja, S., Omar Mohammad, M., \& Hassan, R. (2016). Modelling public behavioral intention to adopt Islamic banking in Uganda: the theory of reasoned action. International Journal of Islamic and Middle Eastern Finance and Management, 9(4), 583-600. https://doi.org/10.1108/IMEFM-08-2015-0092

Mbabazi, P. (2018). Consumer Attitude, Subjective Norms, Perceived Behavioral Controls and Adoption of Online Shopping in Kampala City, Uganda.

Minton, E. A., Spielmann, N., Kahle, L. R., \& Kim, C. H. (2018). The subjective norms of sustainable consumption: A cross-cultural exploration. Journal of Business Research, 82, 400-408. https://doi.org/10.1016/j.jbusres.2016.12.031

Morris, M. W., \& Liu, Z. (2015). Psychological functions of subjective norms: Reference groups, moralization, adherence, and defiance. Journal of Cross-Cultural Psychology, 46(10), 1279-1287. https://doi.org/10.1177/0022022115612161

Nordin, N., Ismail, F., \& Zainuddin, Z. (2018). Crowdfunding: A promising alternative to turn dreams into reality. e-Academia Journal, 6(2).

Pan, Y., \& Liu, Y. (2018, April). Research on Influence of Investors' Willingness to Invest in Equity Crowdfund. In 2018 International Conference on Management and Education, Humanities and Social Sciences (MEHSS 2018). Atlantis Press. https://doi.org/10.2991/mehss-18.2018.75

Shan, Y., \& King, K. W. (2015). The effects of interpersonal tie strength and subjective norms on consumers' brand-related eWOM referral intentions. Journal of Interactive Advertising, 15(1), 16-27. https://doi.org/10.1080/15252019.2015.1016636

Shneor, R., \& Munim, Z. (2019). Reward crowdfunding contribution as planned behaviour: An extended framework. Journal of Business Research, 103(10), 56-70. https://doi.org/10.1016/j.jbusres.2019.06.013

Tiwari, P., \& Bhat, A. K. (2017). The Mediating Role of Subjective Norms in the Formation of Social Entrepreneurial Intentions. In Academy of Management Proceedings (Vol. 2017, No. 1, p. 13429). Briarcliff Manor, NY 10510: Academy of Management. https://doi.org/10.5465/AMBPP.2017.13429abstract

Yunus, M., Mat Som, R., Abdul Majid, A., Aziz, U. A., Munirah, U., Abas, M., \& Khalid, M. (2018). Generation Y Purchase Intention of Personal Care Products: The Influence of Attitude, Subjective Norms and Perceived Behavioural Control. Journal of International Business, Economics and Entrepreneurship, 3(2), 30-36. 
Appendix

SECTION 1: Demographics

Please circle the appropriate box

\begin{tabular}{cccccc}
\hline \multirow{2}{*}{ Age } & $18-22$ & $23-30$ & $31-40$ & $41-50$ & Over 50 \\
\cline { 2 - 5 } & 1 & 2 & 3 & 4 & 5 \\
\hline & & & & \\
\cline { 2 - 5 } & $\begin{array}{l}\text { Marital } \\
\text { Status }\end{array}$ & Single & Married & Other \\
\cline { 2 - 5 }
\end{tabular}

\begin{tabular}{cccc}
\hline \multirow{2}{*}{ Gender } & Male & Female & Other \\
\cline { 2 - 4 } & 1 & 2 & 3 \\
\hline
\end{tabular}

\begin{tabular}{lccccc} 
& Secondary & College & & Ph. \\
Educational & School/High \\
Background & School & Diploma & $\begin{array}{c}\text { Graduate/ } \\
\text { Bachelor's } \\
\text { Degree }\end{array}$ & Master's Degree & $\begin{array}{c}\text { D./Doctorate } \\
\text { Degree }\end{array}$ \\
\cline { 2 - 5 } & 1 & 2 & 3 & 4 & 5 \\
\hline
\end{tabular}

The education level that you have COMPLETED. Not the one you are currently pursuing

\begin{tabular}{lccc}
\hline Family & $\begin{array}{c}\text { Nuclear } \\
\text { family }\end{array}$ & Joint family & Living alone \\
\cline { 2 - 4 } system & 1 & 2 & 3
\end{tabular}

\begin{tabular}{lllllll}
\hline $\begin{array}{l}\text { Number of } \\
\text { friends }\end{array}$ & 1 & 2 & 3 & 4 & 5 & More than 5 \\
\cline { 2 - 7 } & 1 & 2 & 3 & 4 & 5 & 6 \\
\hline
\end{tabular}

\begin{tabular}{|c|c|c|c|c|c|c|c|}
\hline $\begin{array}{l}\text { Person/ group } \\
\text { you follow other }\end{array}$ & Teacher/s & $\begin{array}{c}\text { Boss/Super } \\
\text { visor }\end{array}$ & Advisor & Neighbor & $\begin{array}{l}\text { Religious or } \\
\text { social group }\end{array}$ & $\begin{array}{c}\text { Social } \\
\text { networking } \\
\text { friends }\end{array}$ & None \\
\hline
\end{tabular}

\section{Rank the referent groups according to their influence on you $(1=$ High influence $\& 3=$ least influence)}

\begin{tabular}{llll}
\hline \multirow{2}{*}{ Referent Group } & Family & Friends & Others \\
\cline { 2 - 3 } & & \\
\hline
\end{tabular}




\section{Please circle. 1 = Strongly Disagree, 2 = Disagree, 3 = I Am Not Sure, 4 = Agree, and 5 = Strongly Agree}

\section{SECTION 2:}

\begin{tabular}{lllllll}
\hline Family influence & & & & \\
\hline 1 & I prefer to follow what my family do & 1 & 2 & 3 & 4 & 5 \\
\hline 2 & My family directs my decisions and helps to choose products & 1 & 2 & 3 & 4 & 5 \\
\hline 3 & I listen to my family recommendation while buying anything & 1 & 2 & 3 & 4 & 5 \\
\hline 4 & I always abstain doing things which my family does not approve & 1 & 2 & 3 & 4 & 5 \\
\hline 5 & I prefer to do what my family says me to do & 1 & 2 & 3 & 4 & 5 \\
\hline 6 & Following family decisions are always helpful & 1 & 2 & 3 & 4 & 5
\end{tabular}

\section{SECTION 3:}

\begin{tabular}{llllllll}
\hline Friends influence & & & & \\
\hline 1 & I like to know views of my friends about a product & 1 & 2 & 3 & 4 & 5 \\
\hline 2 & I prefer to follow my friends when I have to make decision & 1 & 2 & 3 & 4 & 5 \\
\hline 3 & My friends always give me right suggestion and advice & 1 & 2 & 3 & 4 & 5 \\
\hline 4 & Friends help me in choosing a better product as they know me better & 1 & 2 & 3 & 4 & 5 \\
\hline 5 & I do not do things which my friends don't feel I should be doing & 1 & 2 & 3 & 4 & 5 \\
\hline
\end{tabular}

\section{SECTION 4:}

\section{Other group/person (other than family and friends)}

1 I follow the people in decision making whom I admire $\quad \begin{array}{lllll}1 & 2 & 3 & 4 & 5\end{array}$

$2 \quad$ I get influenced by the people around me while making decisions $\quad \begin{array}{lllll}1 & 2 & 3 & 4 & 5\end{array}$

3 People who I admire or my role models always give my right suggestion or advice $\quad \begin{array}{lllll}1 & 2 & 4 & 5\end{array}$

4 I prefer to take suggestion and recommendation of people outside my family and friend circle $\quad$\begin{tabular}{lllll}
1 & 2 & 3 & 4 & 5 \\
\hline
\end{tabular}

5 People outside family and friends always give honest opinion $\quad$\begin{tabular}{lllll} 
& 2 & 3 & 4 & 5 \\
\hline
\end{tabular}

\section{SECTION 4:}

\begin{tabular}{lllllll}
\hline Motivation to comply & & & & \\
\hline 1 & I follow what my family says me to do & 1 & 2 & 3 & 4 & 5 \\
\hline 2 & I want to do what my friends think I should do & 1 & 2 & 3 & 4 & 5 \\
\hline 3 & I should follow people around me and do what they want me to do & 1 & 2 & 3 & 4 & 5 \\
\hline 4 & I want to follow my close and important people and do what they think I should do & 1 & 2 & 3 & 4 & 5 \\
\hline
\end{tabular}

\section{SECTION 5:}

\section{Intention to embrace crowdfunding}

$1 \quad$ I prefer to participate in crowdfunding as my referent groups do

\begin{tabular}{lllll}
1 & 2 & 3 & 4 & 5 \\
\hline
\end{tabular}

2 Investing/contributing towards crowdfunding projects is a good idea

\begin{tabular}{lllll}
1 & 2 & 3 & 4 & 5 \\
\hline & 2 & 3 & 4 & 5
\end{tabular}

3 I always keep track of projects present on crowdfunding platform

$\begin{array}{lllll}1 & 2 & 3 & 4 & 5\end{array}$

$4 \quad$ I prefer contributing in Crowdfunding projects than traditional way of financing

\begin{tabular}{lllll}
1 & 2 & 3 & 4 & 5 \\
\hline
\end{tabular}

5 Participating in crowdfunding campaigns is a good choice

$\begin{array}{lllll}1 & 2 & 3 & 4 & 5\end{array}$

6 Crowdfunding contributions results in good returns (financial or non-financial)

$\begin{array}{lllll}1 & 2 & 3 & 4 & 5\end{array}$

